\title{
PENGARUH KOMPETENSI PEMIMPIN, DISIPLIN KERJA DAN IKLIM ORGANISASI TERHADAP PRODUKTIFITAS PEGAWAI
}

\author{
Arif Marjuki $^{l}$ \\ M. Ifran Sanni ${ }^{2}$ \\ Wahyu Hidayat ${ }^{3}$ \\ Dosen AMIK Raharja Informatika ${ }^{1,2}$, Dosen STMIK Raharja ${ }^{3}$ \\ Jl. Jendral Sudirman No. 40, Modern Cikokol, Tangerang ${ }^{1,2,3}$ \\ Email : arif.marjuki@raharja.info ${ }^{1)}$, ifran@raharja.info ${ }^{2)}$, wahyu@raharja.info ${ }^{3)}$
}

\begin{abstract}
ABSTRAK
Penelitian ini bertujuan untuk mengetahui pengaruh kompetensi pemimpin, disiplin kerja dan iklim organisasi secara parsial maupun secara bersama-sama terhadap produktifitas pegawai. Penelitian ini menggunakan metode kuantitatif dengan teknik survei. Instrumen pengumpul data yang digunakan adalah kuesioner tertutup dengan skala likert. Penelitan ini menggunakan sampel acak dengan jumlah responden sebanyak 72 pegawai. Data yang diperoleh dari penelitian ini akan dianalisis dengan menggunakan metode statistik dengan program SPSS versi 19 for windows. Hasil dari penelitian ini menunjukkan bahwa Terdapat pengaruh positif dan signifikan antara kompetensi pemimpin $\left(X_{1}\right)$ terhadap produktifitas pegawai $(Y)$ dengan koefisien determinasi korelasi sebesar 0,312 dengan persamaan regresi sederhana $\hat{Y}=16,095+0,426 X_{1}$. Terdapat pengaruh yang positif dan signifikan antara disiplin kerja $\left(X_{2}\right)$ terhadap produktifitas pegawai $(Y)$ dengan koefisien determinasi korelasi sebesar 0,373 dengan persamaan regresi sederhana $\hat{Y}=23,561+0,463 X_{2}$. Terdapat pengaruh yang positif dan signifikan antara iklim organisasi $\left(X_{3}\right)$ terhadap produktifitas pegawai( $\left.Y\right)$ dengan koefisien determinasi korelasi sebesar 0,323 dengan persamaan regresi sederhana $\hat{Y}=11,292+$ $0,687 X_{3}$. Terdapat pengaruh yang positif dan signifikan kompetensi pemimpin $\left(X_{1}\right)$, disiplin kerja $\left(X_{2}\right)$ daniklim organisasi $\left(X_{3}\right)$ secara bersama-sama terhadap produktifitas pegawai $(Y)$, koefisien determinasi korelasi ganda diperoleh 0,929 dengan persamaan regresi ganda $\hat{Y}=$ $6,312+0,152 X_{1}+0,257 X_{2}+0,306 X_{3}$. Penelitian ini diharapkan dapat bermanfaat bagi perusahaan khususnya untuk meningkatkan produktifitas pegawai secara maksimal. Peneliti menyarankan agar manajemen perusahaan, senantiasa meningkatkan kompetensi pemimpin, disiplin kerja dan iklim organisasi sehingga produktifitas pegawai meningkat dimasa mendatang.
\end{abstract}

Kata Kunci : Kompetensi Pemimpin, Disiplin Kerja, Iklim Organisasi, Produktifitas.

\begin{abstract}
This study aimed to determine the effect of leadership competencies, work discipline and organizational climate partially or jointly against employee productivity. This study uses quantitative methods to survey techniques. Data collection instrument used was a questionnaire enclosed with Likert scale. This research uses a random sample of the number of respondents is 72 employees. Data obtained from this study will be analyzed using statistical methods with SPSS version 19 for Windows. The results of this study indicate that There is a positive and significant influence between the competence leader $\left(\mathrm{X}_{1}\right)$ on the productivity of employees $(\mathrm{Y})$ with a correlation coefficient of determination of 0.312 with a simple regression equation $=16,095+0,426 \mathrm{X}_{1}$. There is a positive and significant effect of labor discipline $\left(\mathrm{X}_{2}\right)$ to the satisfaction of productivity of employees $(\mathrm{Y})$ with a correlation coefficient of determination of 0.373 with a simple regression equation $=23.561+$ $0,463 \mathrm{X}_{2}$. There is a positive and significant influence between organizational climate $\left(\mathrm{X}_{3}\right)$ on productivity of employees $(\mathrm{Y})$ with a correlation coefficient of determination of 0.323 with a simple regression equation $=11.292+0,687 \mathrm{X}_{3}$. There is a positive and significant influence competence leader $\left(\mathrm{X}_{1}\right)$, work discipline $\left(\mathrm{X}_{2}\right)$ and organizational climate $\left(\mathrm{X}_{3}\right)$ together on productivity $(\mathrm{Y})$,
\end{abstract}


multiple correlation coefficient of determination obtained 0,929 with multiple regression equation $=$ $6.312+0,152 \mathrm{X}_{1}+0.257 \mathrm{X}_{2}+0,306 \mathrm{X}_{3}$. This research is expected to be useful for companies in particular to increase employee productivity maximally. Researchers suggest that corporate management, always improve the competence of leaders, work discipline and organizational climate so that employee productivity increases in the future.

Keywords : Competence leader, Discipline of work, organizational climate, Productivity.

\section{PENDAHULUAN}

Masalah sumber daya manusia masih menjadi sorotan dan tumpuhan bagi perusahaan untuk tetap dapat bertahan di era globalisasi. Sumber daya manusia mempunyai peran utama dalam setiap kegiatan perusahaan. Walaupun didukung dengan sarana dan prasarana serta sumber dana yang berlebihan, tetapi tanpa dukungan sumber daya manusia yang andal kegiatan perusahaan tidak akan terselesaikan dengan baik. Hal ini menunjukkan bahwa sumber daya manusia merupakan kunci pokok yang harus diperhatikan dengan segala kebutuhannya. Sebagai kunci pokok, sumber daya manusia akan menentukan keberhasilan pelaksanaan kegiatan perusahaan. Tuntutan perusahaan untuk memperoleh, mengembangkan dan mempertahankan sumber daya manusia yang berkualitas semakin mendesak sesuai dengan dinamika lingkungan yang selalu berubah. Perubahan perlu mendapat dukungan manajemen puncak sebagai langkah pertama yang penting untuk dilakukan bukan hanya sekedar lip service saja. Pemimpin harus dapat memobilisasi sebuah tim, proses pekerjaan harus dapat dikembangkan dan proses sumber daya manusia harus menjadi fokus utama. Perubahan dan peningkatan peran fungsi sumber daya manusia sangat esensial untuk mendukung keberhasilan organisasi. Sumber daya manusia sebagai penggerak organisasi banyak dipengaruhi oleh perilaku para pesertanya (partisipannya) atau aktornya. Keikutsertaan sumber daya manusia dalam organisasi diatur dengan adanya pemberian wewenang dan tanggung jawab. Merumuskan wewenang dan tanggung jawab yang harus dicapai karyawan dengan standar atau tolak ukur yang telah ditetapkan dan disepakati oleh karyawan dan atasan. Karyawan bersama atasan masing-masing dapat menetapkan sasaran kerja dan standar kinerja yang harus dicapai serta menilai hasil-hasil yang sebenarnya dicapai pada akhir kurun waktu tertentu. Peningkatan kinerja karyawan secara perorangan akan mendorong kinerja sumber daya manusia secara keseluruhan, yang direfleksikan dalam kenaikan produktifitas. Penilaian kinerja merupakan suatu hal yang tidak dapat dipisahkan dengan perusahaan. Dukungan dari tiap manajemen yang berupa pengarahan, dukungan sumber daya seperti, memberikan peralatan yang memadai sebagai sarana untuk memudahkan pencapaian tujuan yang ingin dicapai dalam pendampingan, bimbingan, pelatihan serta pengembangan akan lebih mempermudah penilaian kinerja yang obyektif. Dalam lingkungan bisnis yang semakin kompetitif, maka perusahaan dituntut untuk memberdayakan dan mengoptimalkan seluruh sumber daya yang dimiliki, termasuk sumber daya manusia. Mengelola sumber daya manusia di organisasi perusahaan dengan berbagai ragam sifat, sikap dan kemampuan manusia agar mereka dapat bekerja menuju satu tujuan yang direncanakan perusahaan. Sumber daya manusia sebagai pelaku organisasi mempunyai perbedaan dalam sikap (attitude) dan pengalaman (experimen). Perbedaan tersebut menyebabkan tiap individu yang melakukan kegiatan dalam organisasi mempunyai kemampuan kerja atau kinerja (performance) yang masing-masing berbeda juga. 


\section{LANDASAN TEORI}

Peran kepemimpinan sangat penting dalam mengoptimalkan kinerja pegawai, selaras dengan pendapat Morry Taylor dan To Siebel dalam Robbins (2006:435-436) yang menyatakan bahwa pemimpin menetapkan dan menyusun perannya serta peran bawahannya dalam mengupayakan pencapaain sasaran. Hal ini mencakup perilaku yang berupaya mengorganisasi kerja, hubungan kerja dan sasaran. Kepemimpinan menurut Hasibuhan (2006:170) merupakan salah satu cara seorang pemimpin mempengaruhi perilaku bawahannya agar mau bekerja sama dan bekerja secara produktif unutk mencapai tujuan organisasi. Kompetensi pemimpin adalah mempengaruhi dan tidak memaksa untuk memotivasi individu dalam mencapai tujuan". Dengan menciptakan kompetensi pemimpin atau lingkungan kerja yang sekondusif mungkin, efektifitas pimpinan akan sangat meningkat. Dalam sebuah organisasi, diperlukan sebuah pembinaan bagi pegawai untuk mencegah terjadinya pelanggaran-pelanggaran terhadap ketentuan yang telah ditetapkan. Dan seorang pemimpin memerlukan alat untuk melakukan komunikasi dengan para karyawannya mengenai tingkah laku para pegawai dan bagaimana memperbaiki perilaku para pegawai dan bagaimana memperbaiki perilaku para pegawai menjadi lebih baik lagi.

\section{Manajemen}

Pengertian manajemen menurut Robbins dalam bukunya yang berjudul "perilaku organisasi" (2002:7), mengatakan bahwa "manajemen adalah proses mengkoordinasi, dan mengintegrasikan kegiatan-kegiatan kerja agar diselesaikan secara efisien, dan efektif melalui orang lain". Manajemen penting digunakan dalam suatu organisasi, karena manajemen merupakan suatu landasan dalam melakukan kegiatan organisasi, sehingga suatu organisasi dapat melaksanakan kegiatan operasional dari organisasi tersebut. Merekrut dan memberdayakan orang-orang yang kreatif dan berdaya inovasi yang selalu berbeda, yang pikirannya terus berputar, selalu ingin tahu, dan selalu bertanya. Menggunakan tool dalam proses kreativitas guna memecahkan masalah perusahaan. Menggunakan jasa agen kreatif yang dapat membantu dalam memunculkan ide-ide baru bagi perusahaan.

\section{Manajamen Sumber Daya Manusia}

Sumber daya manusia merupakan salah satu sumber daya yang terdapat dalam organisasi. Pengertian manajemen sumber daya manusia suatu ilmu atau cara bagaimana mengatur hubungan dan peranan sumber daya (tenaga kerja) yang dimiliki oleh individu secara efisien dan efektif serta dapat digunakan secara maksimal sehingga tercapai tujuan (goal) bersama perusahaan, karyawan dan masyarakat menjadi maksimal. Manajamen sumber saya manusia didasari pada suatu konsep bahwa setiap karyawan adalah manusia, bukan mesin dan bukan semata menjadi sumber daya bisnis. Kajian manajamen sumber daya manusia menggabungkan beberapa bidang ilmu seperti psikologi, sosiologi.

\section{Disiplin}

Disiplin merupakan suatu kekuatan yang berkembang di dalam tubuh pekerja sendiri yang menyebabkan dia dapat menyesuaikan diri dengan sukarela kepada keputusankeputusan, peraturan-peraturan, dan nilai-nilai tinggi dari pekerjaan dan tingkah laku (Asmiarsih 2006:23). Disiplin karyawan sangat penting bagi suatu perusahaan dalam rangka mewujudkan tujuan perusahaan, hal ini sesuai dengan penjelasan Malayu S.P Hasibuan (2009:213) bahwa: "kedisplinan harus ditegakkan dalam suatu organisasi perusahaan, karena 
tanpa dukungan disiplin karyawan yang baik, maka sulit bagi perusahaan untuk mewujudkan tujuannya".

\section{Iklim Organisasi}

Menurut Davis and Newstrom (2001:25) memandang iklim organisasi sebagai kepribadian sebuah organisasi yang membedakan dengan organisasi lainnya yang mengarah pada persepsi masing-masing anggota dalam memandang organisasi. Iklim organisasi merupakan kualitas lingkungan internal organisasi yang secara relatif terus berlangsung, dialami oleh anggota organisasi, mempengaruhi perilaku mereka dan dapat dilukiskan dalam pengertian satu set karakteristik atau sifat organisasi. Menurut Elvira Sari (2009:2) dalam jurnal iklim organisasi adalah suatu sistem sosial yang selalu dipengaruhi oleh lingkungan baik internal maupun eksternal. Iklim organisasi yang baik penting untuk diciptakan karena merupakan persepsi seorang karyawan tentang apa yang diberikan oleh organisasi dan dijadikan dasar bagi penentuan tingkah laku karyawan selanjutnya. Pengertian iklim organisasi atau suasana kerja dapat bersifat jelas secara fisik, tetapi dapat pula bersifat tidak secara fisik atau emosional. Menurut Wirawan (2009:122) iklim organisasi adalah persepsi anggota organisasi (secara individual atau kelompok) dan mereka yang secara tetap berhubungan dengan organisasi mengenai apa yang ada atau terjadi dilingkungan internal organisasi secara rutin, yang mempengaruhi sikap dan perilaku organisasi dan kinerja anggota organisasi yang kemudian menentukan kinerja organisasi.

\section{Produktifitas Kerja}

Dalam melakukan suatu pekerjaan, seorang karyawan hendaknya memiliki produktifitas kerja yang tinggi. Akan tetapi hal tersebut sulit dicapai, bahkan banyak karyawan yang memiliki produktifitas yang rendah atau semakin menurun walaupun telah banyak memiliki pengalaman kerja dan perusahaan telah melaksanakan pelatihan ataupun pengembangan sumber daya manusianya untuk meningkatkan kemampuan dan motivasi kerja karyawan tersebut. Produktifitas kini banyak dibicarakan oleh banyak orang, batasan mengenai produktifitas pun bisa dilihat dari berbagai sudut pandang, tergantung pada siapa yang mengemukakannya dan apa tujuannya. Untuk memberikan gambaran tentang produktifitas kerja, berikut ini adalah beberapa penjelasan yang berkaitan dengan produktifitas kerja. Menurut Muchdarsyah Sinungan (2003:16), pengertian produktifitas dikelompokan menjadi tiga, yaitu sebagai berikut: Rumusan tradisional bagi keseluruhan produktifitas tidak lain ialah ratio daripada apa yang dihasilkan (output) terhadap keseluruhan peralatan produksi yang dipergunakan (input). Produktifitas pada dasarnya adalah suatu sikap mental yang selalu mempunyai pandangan bahwa mutu kehidupan hari ini lebih baik dari pada kemarin, dan hari esok lebih baik dari hari ini. Produktifitas merupakan interaksi terpadu secara serasi dari tiga faktor esensial, yakni: investasi termasuk penggunaan pengetahuan dan teknologi serta riset, manajemen, dan tenaga kerja. 


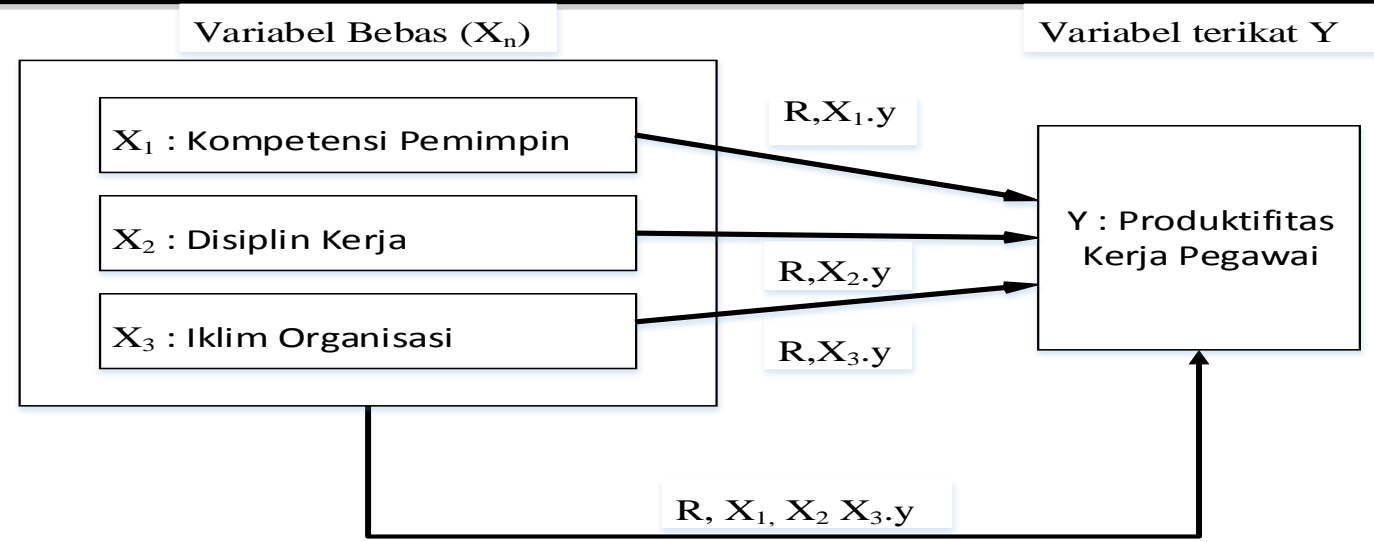

Gambar 1

Diagram Model Penelitian

\section{Keterangan :}

$\mathrm{X}_{1}$ : Kompetensi Pemimpin

$\mathrm{X}_{2}$ : Disiplin Kerja

$\mathrm{X}_{3}$ : Iklim Organisasi

Y :Produktifitas Pegawai

$\mathrm{r}_{1, \mathrm{X}} \mathrm{x}_{1, \mathrm{y}}$ : Kompetensi pemimpinberpengaruh terhadap produktifitas kerja pegawai

$\mathrm{r}_{2, \mathrm{X}} \mathrm{X}, \mathrm{y}$ : Disiplin kerja berpengaruh terhadap produktifitas kerja pegawai

$r_{3}, X_{3}, y$ : Iklim organisasi berpengaruh terhadap produktifitas kerja pegawai

R. $\mathrm{X}_{1}, \mathrm{x}_{2}, \mathrm{x}_{3}, \mathrm{y}$ : Kompetensi pemimpin, disiplin kerja dan iklim organisasi secara bersamasama berpengaruh terhadap produktifitas kerja pegawai.

\section{LITERATURE REVIEW}

\section{PENDARUH KOMPETENSI PEMIMPIN, DISIPLIN KERJA DAN IKLIM} ORCANISASI TERHADAP PRODUKTIVITAS KERJA PEDAWAI Stud' Pada Badan Pengelolaan Dan Pengendalian Dampak Lingkungan (BAPPEDAL) Propinsi Jawa Tengah, oleh Apriyantono Rudy (2002). PROGRAM PASCASARJANA UNIVERSITAS DIPONEGORO. Penelitian yang telah dilakukan di Kantor Badan Pengelolaan Dan Pengendalian Dampak Lingkungan Propinsi Jawa Tengah menjawab permasalahan sentral yang berkaitan dengan pengembangan sumber daya aparatur khususnya yang menyangkut masalah produktivitas kerja pegawai. Secara teoritis dan gejala/fenomena yang ada nampaknya produktivitas kerja pegawai tersebut terbatas dipengaruhi oleh kompetensi pemimpin, disiplin kerja, dan iklim organisasi, karena tidak menutup kemungkinan masih banyaknya faktor-faktor yang mempengaruhi lainnya. Berdasarkan hasil penelitian, variabel kompetensi pemimpin, disiplin kerja, iklim organisasi, dan produktivitas kerja menunjukkan kategori balk. Sedangkan hubungan pengaruh variabel kompetensi pemimpin, disiplin kerja, dan iklim organisasi, terhadap produktivitas kerja dilihat pada tingkat hubungan pengaruhnya satu dengan lainnya berbeda. Di antara ke tiga variabel bebas tersebut yang paling dominan pengaruhnya yaitu variabel kompetensi pemimpin sebesar 0,419 (signifikansi 0,000, dan $\mathrm{z}$ hitung 4,97). Kemudian disusul oleh iklim organisasi sebesar 0,347 (signifikansi 0,000, dan z hitung 4,12), dan variabel disiplin kerja sebesar 0,329 (signifikansi 0,000, dan $\mathrm{z}$ hitung 3,91). Di samping itu terbukti ke tiga variabel bebas tersebut secara parsial mempengaruhi produktivitas kerja, hal ini nampak adanya penurunan angka korelasi yang cukup besar antara variabel bebas dengan variabel tergantung setelah memperhitungkan variabel yang lain yang kemudian dibuat konstan. Juga secara bersama-sama mempengaruhi produktivitas kerja, sebesar 0,514. Lemahnya 
pengaruh kompetensi pemimpin $(41,9 \%)$, disiplin kerja $(32,9 \%)$, dan iklim organisasi $(34,7 \%)$ terhadap produktivitas kerja pegawai disebabkan masih banyaknya pengaruh variabel lain yang perlu diteliti, seperti ketrampilan, sikap dan etika kerja, motivasi, kesempatan berprestasi, dan lain-lain, sehingga berpengaruh pula terhadap kecilnya basil temuan dalam penelitian ini. Walaupun demikian, berdasarkan basil analisis data penelitian dan pembahasan hasil penelitian, maka hipotesis yang dirumuskan telah terjawab atau teruji.

\section{PENGARUH IKLIM ORGANISASI DAN KOMPETENSI KARYAWAN TERHADAP} KINERJA KARYAWAN PADA KSP NASARI CABANG BANDUNG, menurut Fikry Maulidani, Fakultas Ekonomi Universitas Komputer Indonesia, Iklim organisasi yang kondusif untuk memberikan keamanan dan memungkinkan karyawan untuk bekerja dengan optimal Hal ini akan berdampak pada kompetensi karyawan yang diharapkan perusahaan. Dengan kondisi iklim organisasi yang kondusif akan meningkatkan kompetensi pegawai. Bila dikaitkan dengan kinerjanya, hal itu bisa membuat kinerja karyawan perusahaan diharapkan. Kompetensi karyawan sangat penting bagi setiap perusahaan karena karyawan memiliki Tingginya kompetensi suatu perusahaan mampu mencapai target kinerja perusahaan. Diharapkan Hasil analisis jalur menyimpulkan bahwa iklim organisasi berpengaruh signifikan Kompetensi karyawan Iklim organisasi dan kompetensi karyawan keduanya secara simultan Dan sebagian berpengaruh signifikan terhadap kinerja karyawan. Secara simultan mempengaruhi sebesar $78 \%$ Yang paling berpengaruh terhadap kinerja karyawan adalah kompetensi pegawai sebesar 57,4\% Dan dampak iklim organisasi sebesar 20,6\% sedangkan yang mempengaruhi kinerja karyawan tidakLangsung atau dari faktor lain sebesar $22 \%$.

\section{PENGARUH DISIPLIN, KOMPETENSI DAN KEPEMIMPINAN TERHADAP} KINERJA PEGAWAI DINAS TENAGA KERJA KOTA SAMARINDA, oleh Andi Juned, LCA. Robin Jonathan, Elfreda Aplonia Lau, Penelitian ini bertujuan Penelitian ini bertujuan : Untuk mengetahui dan menganalisis pengaruh Disiplin, Kompetensi, dan Kepemimpinansecara langsung (simultan) terhadapKinerja Pegawai Dinas Tenaga Kerja Kota Samarinda. Untuk mengetahui dan menganalisis pengaruh Disiplin terhadapKinerja Pegawai Dinas Tenaga Kerja Kota Samarinda. Untuk mengetahui dan menganalisis pengaruh Kompetensi terhadapKinerja Pegawai Dinas Tenaga Kerja Kota Samarinda. Untuk mengetahui dan menganalisis pengaruh Kepemimpinan terhadapKinerja Pegawai Dinas Tenaga Kerja Kota Samarinda. Dasar teori yang digunakan adalah Manajemen Sumber Daya Manusia yang berfokus pada Disiplin, Kompetensi dan Kinerja Pegawai. Hipotesis penelitian ini adalah 1) Disiplin, Kompetensi, dan Kepemimpinan secara langsung (Bersama-sama) berpengaruh signifikan terhadap Kinerja Pegawai Dinas Tenaga Kerja Kota Samarinda. 2) Disiplin memiliki pengaruh signifikan terhadapKinerja Pegawai Dinas Tenaga Kerja Kota Samarinda. 3) Kompetensi memiliki pengaruh signifikan terhadapKinerja Pegawai Dinas Tenaga Kerja Kota Samarinda. 4)Kepemimpinan memiliki pengaruh signifikan terhadap Kinerja Pegawai Dinas Tenaga Kerja Kota Samarinda.Alatanalisis yang digunakan adalah Regresi Linier Berganda. Hasil penelitian diperoleh bahwa Dari hasil pengujian dengan uji regresi, Variabel disiplin, kompetensi dan kepemimpinan secara bersama-sama berpengaruh secara signifikan terhadap kinerja pegawai Dinas Tenaga Kerja Kota Samarinda. Ada pengaruh yang signifikan antara variabel disiplin terhadap kinerja pegawai Dinas Tenaga Kerja Kota Samarinda. Ada pengaruh yang signifikan antara variabel kompetensi terhadap kinerja pegawai Dinas Tenaga Kerja Kota Samarinda. Ada pengaruh yang signifikan antara variabel kepemimpinan terhadap kinerja pegawai Dinas Tenaga Kerja Kota Samarinda. 


\section{Metode Penelitian}

Metode penelitian yang digunakan adalah metode penelitian deskriptif dan kuantitatif. Menurut Erlina (2008:20), penelitian deskriptif adalah penelitian terhadap fenomena atau populasi tertentu yang diperoleh oleh peneliti dari subjek berupa individu, organisasional, industri atau perspektif yang lain. Penelitian deskriptif dilakukan untuk menjawab pertanyaan tentang: apa, siapa, kapan, di mana, dan bagaimana yang berkaitan dengan karakteristik populasi atau fenomena tersebut. Untuk memudahkan dalam melakukan penelitian yang berhubungan dengan masalah yang diteliti, maka penulis melakukan pendekatan studi kasus. Dengan menggunakan pendekatan ini, data yang dikumpulkan dapat disesuaikan dengan keadaan yang sebenarnya dan dibandingkan dengan teori yang menunjang. Dengan demikian, dapat memberikan gambaran yang cukup jelas serta dapat menarik kesimpulan dari objek yang diteliti. Penelitian ini merupakan penelitian kausal yaitu penelitian yang mengukur kekuatan hubungan variable atau lebih, juga unutk menunjukkan arah hubungan antara variable bebas dengan variabel terikat (Mudrajad, 2009:15). Dengan kata lain mempertanyakan sebab akibat.

\section{Variabel Penelitian}

Suatu atribut atau sifat atau nilai dari orang, obyek atau kegiatan yang mempunyai variasi tertentu yang ditetapkan oleh peneliti untuk dipelajari dan ditarik kesimpulannya. Dalam penelitian ini terdapat dua variabel yaitu variabel independen dan variable dependen, sebagai berikut :

1) Variabel-variabel bebas (Independent variable) Variabel bebas yang dalam hubungannya dengan variabel lain bertindak sebagai penyebab atau yang mempengaruhi variabel dependen. Variabel ini ada juga yang menamakan dengan variabel pendorong. Pada penelitian ini sebagai variabel independen kompetensi pemimpin, disiplin kerja dan iklim organisasi. Variabel independen sering disebut sebagai prediktor yang dilambangkan dengan $\mathrm{X}$.

2) Variabel terikat (dependent variable) Variabel yang tergantung dengan variabel lain, atau variabel yang dapat mempengaruhi oleh variabel lain. Sering disebut variabel respon dimana dalam penelitian ini adalah produktifitas kerja karyawan yang dilambangkan dengan $\mathrm{Y}$. 
Tabel 1.1

Kisi-kisi Variabel Kompetensi Pemimpin

\begin{tabular}{|c|c|c|}
\hline No & Dimensi & Indikator \\
\hline 1 & Kelompok Berprestasi & $\begin{array}{l}\text { 1. Orientasi prestasi } \\
\text { 2. Berhubungan dengan perintah } \\
\text { 3. Inisiatif }\end{array}$ \\
\hline 2 & Kelompok Melayani & $\begin{array}{l}\text { 1. Pemahaman hubungan antar pribadi } \\
\text { 2. Orientasi customer service }\end{array}$ \\
\hline 3 & Kelompok Pengaruh & $\begin{array}{l}\text { 1. Berdampak dan mempengaruhi. } \\
\text { 2. Kesadaran organisasi } \\
\text { 3. Hubungan yang membangun } \\
\text { (Networking) }\end{array}$ \\
\hline 4 & $\begin{array}{l}\text { Kelompok } \\
\text { Berpikir/Pemecahan Masalah }\end{array}$ & $\begin{array}{ll}\text { 1. } & \text { Keahlian teknis } \\
\text { 2. } & \text { Pencarian Informasi } \\
\text { 3. } & \text { Berpikir analisis } \\
\text { 4. } & \text { Berfikir konseptual }\end{array}$ \\
\hline 5 & $\begin{array}{l}\text { Kelompok Pribadi Yang } \\
\text { Efektif }\end{array}$ & $\begin{array}{ll}\text { 1. } & \text { Pengendalian diri } \\
\text { 2. } & \text { Keyakinan diri } \\
\text { 3. } & \text { Komitmen organisasi } \\
\text { 4. } & \text { Fleksibilitas }\end{array}$ \\
\hline
\end{tabular}

Sumber : Mc Clelland Dalam Rahmi Dan Kawan-kawan (2012:120)

a) Variabel Disiplin Kerja (X2)

Disiplin kerja adalah suatu sikap, tingkah laku dan perbuatan yang menunjukkan ketaatan terhadap peraturan yang diwajibkan atau diharapkan oleh organisasi, agar karyawan yang bersangkutan dapat melaksanakan tugas pekerjaannya dengan tertib dan lancar.

b) Variabel Iklim Organisasi (X3)

Iklim organisasi mencerminkan kondisi internal suatu organisasi karena iklim hanya dapat dirasakan oleh anggota organisasi tersebut, dan iklim dapat menjadi sarana untuk mencari penyebab perilaku negatif yang muncul pada karyawan.

c) Variabel Terikat Produktivitas Karyawan (dependent variable)

Produktivitas kerja adalah tingkat sampai dimana tugas-tugas terlaksana sesuai dengan ketentuan yang berlaku dalam menghasilkan barang atau jasa yang diperuntukan bagi masyarakat.

d) Variabel Terikat Produktivitas Karyawan (dependent variable)

Produktivitas kerja adalah tingkat sampai dimana tugas-tugas terlaksana sesuai dengan ketentuan yang berlaku dalam menghasilkan barang atau jasa yang diperuntukan bagi masyarakat. 
Tabel 1.2

Kisi-kisi Variabel Disiplin Kerja

\begin{tabular}{|c|l|l|}
\hline No & \multicolumn{1}{|c|}{ Dimensi } & \multicolumn{1}{c|}{ Indikator } \\
\hline 1 & Struktur & $\begin{array}{l}\text { 1. Kepemimpinan } \\
\text { 2. Deskripsi pekerjaan }\end{array}$ \\
\hline 2 & Standar-standar & $\begin{array}{l}\text { 1. Standar kerja } \\
\text { 2. Harapan tentang kualitas }\end{array}$ \\
\hline 3 & Tanggung jawab & $\begin{array}{l}\text { 1. Pelaksanaan nilai } \\
\text { 2. Pelaksananan norma }\end{array}$ \\
\hline 4 & Pengakuan & $\begin{array}{l}\text { 1. Kenaikan jabatan } \\
\text { 2. Status pekerjaan }\end{array}$ \\
\hline 5 & Dukungan & $\begin{array}{l}\text { 1. Fasilitas Pekerjaan } \\
\text { 2. Hubungan atasan dengan bawahan }\end{array}$ \\
\hline 6 & Komitmen & $\begin{array}{l}\text { 1. Disiplin kerja } \\
\text { 2. Loyalitas kerja }\end{array}$ \\
\hline
\end{tabular}

Sumber : Hasibuan (2005:194)

Tabel 1.3

Kisi-kisi Variabel Iklim Organisasi

\begin{tabular}{|c|l|l|}
\hline No & \multicolumn{1}{|c|}{ Dimensi } & \multicolumn{1}{c|}{ Indikator } \\
\hline 1 & Tujuan disiplin kerja & 1. Persentase kehadiran \\
& & 2. Tepat waktu dating bekerja \\
& & 3. Sesuai dengan rencana dan jadwal \\
& & 4. Menyelesaikan tujuan pekerjaan \\
& & 5. Mengembangkan kemampuan \\
\hline 2 & Faktor pendukung kerja & 1. Teladan pimpinan \\
& disiplin & 2. Balas jasa \\
& & 3. Keadilan \\
\hline 3 & Faktor penentu disiplin Dan & 1. Pengawasan melekat \\
& sanksi & 2. Sanksi hukuman \\
& & 3. Ketegasan \\
& & 4. Hubungan kemanusiaan \\
\hline
\end{tabular}

Tabel 1.4

Kisi-kisi Variabel Produktifitas

\begin{tabular}{|c|l|l|}
\hline No & \multicolumn{1}{|c|}{ Dimensi } & \multicolumn{1}{c|}{ Indikator } \\
\hline 1 & Sikap kerja & $\begin{array}{l}\text { 1. Kesediaan untuk bekerja secara shift. } \\
\text { 2. Kesediaan menerima tambahan tugas. } \\
\text { 3. Dapat bekerja secara tim. }\end{array}$ \\
\hline 2 & Tingkat pendidikan & 1. Pendidikan menentukan keahlian. \\
\hline 3 & Tingkat keterampilan & 2. Pelatihan terhadap karyawan. \\
\hline 4 & Manajemen & $\begin{array}{l}\text { 1. Atasan memberi dorongan kepada bawahan } \\
\text { untuk melakukan tindakan yang produktif. } \\
\text { 2. Diadakan acara rutinitas family gathering. }\end{array}$ \\
\hline 5 & Hubungan industrial & $\begin{array}{l}\text { 1. Menciptakan hubungan tenaga kerja yang } \\
\text { harmonis. } \\
\text { 2. Menjalankan peraturan pemerintah. }\end{array}$ \\
\hline
\end{tabular}




\begin{tabular}{|c|c|c|}
\hline 6 & Gizi dan kesehatan & $\begin{array}{l}\text { 1. Diberikan uang makan. } \\
\text { 2. Diberikan uang shift. }\end{array}$ \\
\hline 7 & Jaminan sosial & $\begin{array}{l}\text { 1. Diberikan asuransi kesehatan (BPJS). } \\
\text { 2. Diberikan Jaminan hari tua dari jamsostek. } \\
\text { 3. Diberikan asuransi jiwa (Jamsostek). }\end{array}$ \\
\hline 8 & Lingkungan dan iklim kerja & $\begin{array}{l}\text { 1. Lingkungan kerja yang humanis. } \\
\text { 2. Diberikan alat pelindung diri. } \\
\text { 3. Diadakan kompetisi olahraga antar bagian. }\end{array}$ \\
\hline 9 & Sarana produksi & $\begin{array}{l}\text { 1. Diberikan sarana prasana dalam melakukan } \\
\text { kegiatan (bekerja). }\end{array}$ \\
\hline 10 & Teknologi & 1. Menggunakan teknologi tepat guna. \\
\hline 11 & Kesempatan berprestasi & $\begin{array}{l}\text { 1. Diberikan penghargaan terhadap karyawan } \\
\text { yang masa kerja } 10 \text { tahun keatas. }\end{array}$ \\
\hline
\end{tabular}

Sumber : Sedarmayanti (2001:72)

\section{PEMBAHASAN}

\section{Uji Validitas Instrumen Variabel Kompetensi Pemimpin $\left(\mathbf{X}_{1}\right)$}

Hasil uji validitas instrumen kompetensi pemimpin $\left(\mathrm{X}_{1}\right)$ dalam penelitian ini dapat dilihat pada tabel berikut :

Tabel 1.5

Hasil Uji Validitas Variabel Kompetensi Pemimpin $\left(\mathbf{X}_{1}\right)$

\begin{tabular}{|c|l|c|c|c|}
\hline No & Pernyataan & r hitung & r tabel & Ket \\
\hline 1 & Kuesioner1 & 0,357 & 0,229 & Valid \\
\hline 2 & Kuesioner2 & 0,581 & 0,229 & Valid \\
\hline 3 & Kuesioner3 & 0,589 & 0,229 & Valid \\
\hline 4 & Kuesioner4 & 0,570 & 0,229 & Valid \\
\hline 5 & Kuesioner5 & 0,580 & 0,229 & Valid \\
\hline 6 & Kuesioner6 & 0,610 & 0,229 & Valid \\
\hline 7 & Kuesioner7 & 0,229 & 0,229 & Valid \\
\hline 8 & Kuesioner8 & 0,367 & 0,229 & Valid \\
\hline 9 & Kuesioner9 & 0,235 & 0,229 & Valid \\
\hline 10 & Kuesioner10 & 0,735 & 0,229 & Valid \\
\hline 11 & Kuesioner11 & 0,792 & 0,229 & Valid \\
\hline 12 & Kuesioner12 & 0,667 & 0,229 & Valid \\
\hline 13 & Kuesioner13 & 0,483 & 0,229 & Valid \\
\hline 14 & Kuesioner14 & 0,510 & 0,229 & Valid \\
\hline 15 & Kuesioner15 & 0,609 & 0,229 & Valid \\
\hline 16 & Kuesioner16 & 0,484 & 0,229 & Valid \\
\hline 17 & Kuesioner17 & 0,506 & 0,229 & Valid \\
\hline 18 & Kuesioner18 & 0,403 & 0,229 & Valid \\
\hline
\end{tabular}

Sumber : Data Primer yang telah diolah (2015).

Tabel 4.1.di atas menunjukkan bahwa seluruh butir instrumen lebih besar dari pada $\mathrm{r}$ product moment sehingga seluruh butir instrumen kompetensi pemimpin $\left(\mathrm{X}_{1}\right)$ dinyatakan valid. Butir instrumen yang memiliki validitas tertinggi adalah butir ke sebelas yaitu sebesar 0,792 dan paling rendah adalah butir ke tujuh yaitu sebesar 0,229. 


\section{Uji Validitas Instrumen Variabel Disiplin Kerja $\left(\mathbf{X}_{2}\right)$}

Hasil uji validitas instrumen disiplin kerja $\left(\mathrm{X}_{2}\right)$ dalam penelitian ini dapat dilihat pada tabel berikut :

Tabel 1.6

Hasil Uji Validitas Variabel Disiplin Kerja $\left(\mathbf{X}_{2}\right)$

\begin{tabular}{|c|c|c|c|c|}
\hline No & Pernyataan & r hitung & r tabel & Ket \\
\hline 1 & Kuesioner1 & 0,470 & 0,229 & Valid \\
\hline 2 & Kuesioner2 & 0,440 & 0,229 & Valid \\
\hline 3 & Kuesioner3 & 0,789 & 0,229 & Valid \\
\hline 4 & Kuesioner4 & 0,638 & 0,229 & Valid \\
\hline 5 & Kuesioner5 & 0,355 & 0,229 & Valid \\
\hline 6 & Kuesioner6 & 0,474 & 0,229 & Valid \\
\hline 7 & Kuesioner7 & 0,585 & 0,229 & Valid \\
\hline 8 & Kuesioner8 & 0,676 & 0,229 & Valid \\
\hline 9 & Kuesioner9 & 0,643 & 0,229 & Valid \\
\hline 10 & Kuesioner10 & 0,755 & 0,229 & Valid \\
\hline 11 & Kuesioner11 & 0,595 & 0,229 & Valid \\
\hline 12 & Kuesioner12 & 0,703 & 0,229 & Valid \\
\hline 13 & Kuesioner13 & 0,530 & 0,229 & Valid \\
\hline 14 & Kuesioner14 & 0,579 & 0,229 & Valid \\
\hline
\end{tabular}

Sumber: Data Primer yang telah diolah (2015)

Tabel 4.2.di atas menunjukkan bahwa seluruh butir instrumen lebih besar dari pada $\mathrm{r}$ product moment sehingga seluruh butir instrumen disiplin kerja $\left(\mathrm{X}_{2}\right)$ dinyatakan valid. Butir instrumen yang memiliki validitas tertinggi adalah butir ke tiga yaitu sebesar 0,789 dan paling rendah adalah butir ke lima yaitu sebesar 0,355 .

\section{Uji Validitas Instrumen Variabel Iklim Organisasi $\left(\mathbf{X}_{3}\right)$}

Hasil uji validitas instrumen iklim organisasi $\left(\mathrm{X}_{3}\right)$ dalam penelitian ini dapat dilihat pada tabel berikut :

Tabel 1.7

Hasil Uji Validitas Variabel Iklim Organisasi $\left(\mathbf{X}_{3}\right)$

\begin{tabular}{|c|c|c|c|c|}
\hline No & Pernyataan & $\mathbf{r}$ hitung & $\mathbf{r}$ tabel & Ket \\
\hline 1 & Kuesioner1 & 0,667 & 0,229 & Valid \\
\hline 2 & Kuesioner2 & 0,535 & 0,229 & Valid \\
\hline 3 & Kuesioner3 & 0,447 & 0,229 & Valid \\
\hline 4 & Kuesioner4 & 0,479 & 0,229 & Valid \\
\hline 5 & Kuesioner5 & 0,593 & 0,229 & Valid \\
\hline 6 & Kuesioner6 & 0,718 & 0,229 & Valid \\
\hline 7 & Kuesioner7 & 0,374 & 0,229 & Valid \\
\hline 8 & Kuesioner8 & 0,564 & 0,229 & Valid \\
\hline 9 & Kuesioner9 & 0,443 & 0,229 & Valid \\
\hline 10 & Kuesioner10 & 0,521 & 0,229 & Valid \\
\hline 11 & Kuesioner11 & 0,239 & 0,229 & Valid \\
\hline
\end{tabular}




\begin{tabular}{|l|l|l|l|l|}
\hline 12 & Kuesioner12 & 0,245 & 0,229 & Valid \\
13 & Kuesioner13 & 0,402 & 0,229 & Valid \\
\hline
\end{tabular}

Sumber : Data Primer yang telah diolah (2015)

Tabel 4.3.di atas menunjukkan bahwa seluruh butir instrumen lebih besar dari pada $\mathrm{r}$ product moment sehingga seluruh butir instrumen iklim organisasi $\left(\mathrm{X}_{3}\right)$ dinyatakan valid. Butir instrumen yang memiliki validitas tertinggi adalah butir ke enam yaitu sebesar 0,718 dan paling rendah adalah butir ke sebelas yaitu sebesar 0,239.

\section{Uji Validitas Instrumen Variabel Produktifitas (Y)}

Hasil uji validitas instrumen produktifitas (Y) dalam penelitian ini dapat dilihat pada tabel berikut :

Tabel 1.8

Hasil Uji Validitas Variabel Produktifitas (Y)

\begin{tabular}{|c|c|c|c|c|}
\hline No & Pernyataan & r hitung & r tabel & Ket \\
\hline 1 & Kuesioner1 & 0,655 & 0,229 & Valid \\
\hline 2 & Kuesioner2 & 0,425 & 0,229 & Valid \\
\hline 3 & Kuesioner3 & 0,519 & 0,229 & Valid \\
\hline 4 & Kuesioner4 & 0,613 & 0,229 & Valid \\
\hline 5 & Kuesioner5 & 0,433 & 0,229 & Valid \\
\hline 6 & Kuesioner6 & 0,290 & 0,229 & Valid \\
\hline 7 & Kuesioner7 & 0,752 & 0,229 & Valid \\
\hline 8 & Kuesioner8 & 0,561 & 0,229 & Valid \\
\hline 9 & Kuesioner9 & 0,623 & 0,229 & Valid \\
\hline 10 & Kuesioner10 & 0,589 & 0,229 & Valid \\
\hline 11 & Kuesioner11 & 0,373 & 0,229 & Valid \\
\hline 12 & Kuesioner12 & 0,256 & 0,229 & Valid \\
\hline
\end{tabular}

Sumber: Data Primer yang telah diolah (2015)

Tabel 4.4.di atas menunjukkan bahwa seluruh butir instrumen lebih besar dari pada $\mathrm{r}$ product moment sehingga seluruh butir instrumen produktifitas (Y) dinyatakan valid. Butir instrumen yang memiliki validitas tertinggi adalah butir ke tujuh yaitu sebesar 0,752 dan paling rendah adalah butir ke duabelas yaitu sebesar 0,256.

\section{Variabel Kompetensi Pemimpin $\left(\mathbf{X}_{1}\right)$}

Kompetensi pemimpin adalah kemampuan para kepala bidang dalam mengarahkan tugas-tugas, melakukan komunikasi dengan bawahan, menggerakan dan mendorong semangat para pegawai bawahan, agar melaksanakan tugas-tugas secara efektif, tertib dan lancar. Adapun jawaban para responden atas kompetensi pemimpin PT. Indoseiki Metalutama dapat dipaparkan sebagai berikut : 
Tabel 1.9

Deskriptif Variabel Kompetensi Pemimpin

\begin{tabular}{|c|c|c|c|c|c|c|c|c|c|c|c|c|}
\hline \multirow[b]{2}{*}{$\begin{array}{l}\mathbf{N} \\
\mathbf{0}\end{array}$} & \multirow[b]{2}{*}{ Pernyataan } & \multicolumn{2}{|c|}{ SS } & \multicolumn{2}{|r|}{$\mathbf{S}$} & \multicolumn{2}{|r|}{$\mathbf{R}$} & \multicolumn{2}{|c|}{ TS } & \multicolumn{2}{|c|}{ STS } & \multirow{2}{*}{$\begin{array}{l}\text { Skor } \\
\text { Total }\end{array}$} \\
\hline & & $\mathbf{F}$ & $\%$ & $\mathbf{F}$ & $\%$ & $\mathbf{F}$ & $\%$ & $\mathbf{F}$ & $\%$ & $\mathbf{F}$ & $\%$ & \\
\hline 1 & $\begin{array}{l}\text { Diikutsertakan bawahan } \\
\text { dalam pertemuan/rapat. }\end{array}$ & 18 & $25,00 \%$ & 41 & $56,94 \%$ & 8 & $11,11 \%$ & 5 & $6,94 \%$ & 0 & $0,00 \%$ & 288 \\
\hline 2 & $\begin{array}{l}\text { Bawahan diberikan } \\
\text { kesempatan } \\
\text { mengemukakan } \\
\text { pendapat/usulan terhadap } \\
\text { masalah-masalah yang } \\
\text { dihadapi dalam } \\
\text { pelaksanaan tugas. }\end{array}$ & 43 & $59,72 \%$ & 29 & $40,28 \%$ & 0 & $0,00 \%$ & 0 & $0,00 \%$ & 0 & $0,00 \%$ & 331 \\
\hline 3 & $\begin{array}{l}\text { Memberikan saran-saran } \\
\text { dan masukan kepada } \\
\text { pemimpin. }\end{array}$ & 25 & $34,72 \%$ & 38 & $52,78 \%$ & 8 & $11,11 \%$ & 1 & $1,39 \%$ & 0 & $0,00 \%$ & 303 \\
\hline 4 & $\begin{array}{l}\text { Kejelasan informasi- } \\
\text { informasi yang } \\
\text { disampaikan. }\end{array}$ & 33 & $45,83 \%$ & 35 & $48,61 \%$ & 4 & $5,56 \%$ & 0 & $0,00 \%$ & 0 & $0,00 \%$ & 317 \\
\hline 5 & $\begin{array}{l}\text { Kejelasan setiap perintah } \\
\text { atau intruksi-intruksi } \\
\text { yang disampaikan kepada } \\
\text { bawahan. }\end{array}$ & 33 & $45,83 \%$ & 36 & $50,00 \%$ & 3 & $4,17 \%$ & 0 & $0,00 \%$ & 0 & $0,00 \%$ & 318 \\
\hline 6 & $\begin{array}{l}\text { Pemakaian bahasa dan } \\
\text { istilah-istilah yang muda } \\
\text { dipahami bawahan. }\end{array}$ & 37 & $51,39 \%$ & 32 & $44,44 \%$ & 1 & $1,39 \%$ & 2 & $2,78 \%$ & 0 & $0,00 \%$ & 320 \\
\hline 7 & $\begin{array}{l}\text { Adanya penghargaan dari } \\
\text { pimpinan atas } \\
\text { prestasi/hasil yang } \\
\text { dicapai oleh bawahan. }\end{array}$ & 49 & $68,06 \%$ & 20 & $27,78 \%$ & 3 & $4,17 \%$ & 0 & $0,00 \%$ & 0 & $0,00 \%$ & 334 \\
\hline 8 & $\begin{array}{l}\text { Adanya bantuan yang } \\
\text { diberikan oleh pimpinan } \\
\text { atas kesulitan-kesulitan } \\
\text { yang dihadapi bawahan. }\end{array}$ & 36 & $50,00 \%$ & 35 & $48,61 \%$ & 1 & $1,39 \%$ & 0 & $0,00 \%$ & 0 & $0,00 \%$ & 323 \\
\hline 9 & $\begin{array}{l}\text { Pemberian contoh sesuatu } \\
\text { yang belum diketahui } \\
\text { bawahan }\end{array}$ & 29 & $40,28 \%$ & 42 & $58,33 \%$ & 1 & $1,39 \%$ & 0 & $0,00 \%$ & 0 & $0,00 \%$ & 321 \\
\hline 10 & $\begin{array}{l}\text { Atasan bertanggung } \\
\text { Jawab atas pekerjaan } \\
\text { bawahannya. }\end{array}$ & 35 & $48,61 \%$ & 33 & $45,83 \%$ & 4 & $5,56 \%$ & 0 & $0,00 \%$ & 0 & $0,00 \%$ & 324 \\
\hline 11 & $\begin{array}{l}\text { Atasan siap menerima } \\
\text { tantangan demi kemajuan } \\
\text { perusahaan. }\end{array}$ & 32 & $44,44 \%$ & 34 & $47,22 \%$ & 6 & $8,33 \%$ & 0 & $0,00 \%$ & 0 & $0,00 \%$ & 319 \\
\hline 12 & $\begin{array}{l}\text { Atasan mempuanyai } \\
\text { target pekerjaan. }\end{array}$ & 21 & $29,17 \%$ & 40 & $55,56 \%$ & 9 & $12,50 \%$ & 0 & $0,00 \%$ & 2 & $2,78 \%$ & 298 \\
\hline 13 & $\begin{array}{l}\text { Atasan mengerti semua } \\
\text { pekerjaan yang akan } \\
\text { dilakukan oleh anak } \\
\text { buahnya. }\end{array}$ & 27 & $37,50 \%$ & 43 & $59,72 \%$ & 2 & $2,78 \%$ & 0 & $0,00 \%$ & 0 & $0,00 \%$ & 318 \\
\hline 14 & $\begin{array}{l}\text { Atasan terampil dalam } \\
\text { bidangnya. }\end{array}$ & 33 & $45,83 \%$ & 37 & $51,39 \%$ & 2 & $2,78 \%$ & 0 & $0,00 \%$ & 0 & $0,00 \%$ & 323 \\
\hline 15 & $\begin{array}{l}\text { Atasan menerima adanya } \\
\text { perbedaan pendapat yang } \\
\text { tidak sesuai dengan } \\
\text { pendapat saya. }\end{array}$ & 17 & $23,61 \%$ & 44 & $61,11 \%$ & 6 & $8,33 \%$ & 3 & $4,17 \%$ & 2 & $2,78 \%$ & 291 \\
\hline
\end{tabular}




\begin{tabular}{|c|c|c|c|c|c|c|c|c|c|c|c|c|}
\hline 16 & $\begin{array}{l}\text { Atasan berusaha menahan } \\
\text { emosi ketika melihat saya } \\
\text { bekerja menyimpang dari } \\
\text { SOP. }\end{array}$ & 10 & $13,89 \%$ & 43 & $59,72 \%$ & 10 & $13,89 \%$ & 8 & $11,11 \%$ & 1 & $1,39 \%$ & 273 \\
\hline 17 & $\begin{array}{l}\text { Atasan dapat } \\
\text { mengendalikan hasil } \\
\text { produksi sesuai dengan } \\
\text { target. }\end{array}$ & 20 & $27,78 \%$ & 34 & $47,22 \%$ & 15 & $20,83 \%$ & 2 & $2,78 \%$ & 1 & $1,39 \%$ & 291 \\
\hline 18 & $\begin{array}{l}\text { Atasan mempunyai } \\
\text { komitmen yang tinggi } \\
\text { terhadap hasil produksi }\end{array}$ & 32 & $44,44 \%$ & 30 & $41,67 \%$ & 8 & $11,11 \%$ & 1 & $1,39 \%$ & 1 & $1,39 \%$ & 311 \\
\hline & Jumlah & 530 & $40,90 \%$ & 646 & $49,85 \%$ & 91 & $7,02 \%$ & 22 & $1,70 \%$ & 7 & $0,54 \%$ & \\
\hline
\end{tabular}

Sumber : Data primer yang telah diolah (2015).

\section{Variabel Disiplin Kerja $\left(\mathbf{X}_{2}\right)$}

Disiplin kerja di lingkungan PT. Indoseiki Metalutama yaitu mengenai sikap, tingkah laku dan perbuatan yang menunjukan ketaatan terhadap peraturan yang diwajibkan atau diharapkan oleh organisasi, agar pegawai yang bersangkutan dapat melaksanakan tugas pekerjaannya dengan tertib dan lancar. Adapun penilaian respondenatas disiplin kerja karyawan pada PT. Indoseiki Metalutama dapat dipaparkan sebagai berikut :

Tabel 1.10

Deskriptif Variabel Disiplin Kerja

\begin{tabular}{|c|c|c|c|c|c|c|c|c|c|c|c|c|}
\hline \multirow{2}{*}{ No } & \multirow{2}{*}{ Pernyataan } & \multicolumn{2}{|c|}{ SS } & \multicolumn{2}{|c|}{$\mathbf{S}$} & \multicolumn{2}{|r|}{$\mathbf{R}$} & \multicolumn{2}{|c|}{ TS } & \multicolumn{2}{|c|}{ STS } & \multirow{2}{*}{$\begin{array}{l}\text { Skor } \\
\text { Total }\end{array}$} \\
\hline & & $\mathbf{F}$ & $\%$ & $\mathbf{F}$ & $\%$ & $\mathbf{F}$ & $\%$ & $\mathbf{F}$ & $\%$ & $\mathbf{F}$ & $\%$ & \\
\hline 1 & $\begin{array}{l}\text { Ketepatan } \\
\text { datang dan } \\
\text { pulang dari } \\
\text { tempat kerja. }\end{array}$ & 27 & $36,99 \%$ & 42 & $57,53 \%$ & 1 & $1,37 \%$ & 1 & $1,37 \%$ & 1 & $1,37 \%$ & 313 \\
\hline 2 & $\begin{array}{l}\text { Kesediaan } \\
\text { karyawan } \\
\text { mengerjakan } \\
\text { tugas setelah } \\
\text { jam kerja } \\
\text { selesai. }\end{array}$ & 2 & $2,74 \%$ & 21 & $28,77 \%$ & 34 & $46,58 \%$ & 13 & $17,81 \%$ & 2 & $2,74 \%$ & 225 \\
\hline 3 & $\begin{array}{l}\text { Pada jam kerja } \\
\text { karyawan dapat } \\
\text { memaksimalkan } \\
\text { pekerjaanya. }\end{array}$ & 21 & $28,77 \%$ & 47 & $64,38 \%$ & 4 & $5,48 \%$ & 0 & $0,00 \%$ & 0 & $0,00 \%$ & 309 \\
\hline 4 & $\begin{array}{l}\text { Kesungguhan } \\
\text { dalam } \\
\text { melaksanakan } \\
\text { tugas. }\end{array}$ & 39 & $53,42 \%$ & 31 & $42,47 \%$ & 2 & $2,74 \%$ & 0 & $0,00 \%$ & 0 & $0,00 \%$ & 329 \\
\hline 5 & $\begin{array}{l}\text { Tidak suka } \\
\text { membuang- } \\
\text { buang waktu } \\
\text { kerja dengan } \\
\text { kegiatan lain } \\
\text { yang tidak } \\
\text { berkaitan } \\
\text { dengan tugas. }\end{array}$ & 27 & $36,99 \%$ & 38 & $52,05 \%$ & 6 & $8,22 \%$ & 1 & $1,37 \%$ & 0 & $0,00 \%$ & 309 \\
\hline
\end{tabular}


ISSN : 2356 -5209

\begin{tabular}{|c|c|c|c|c|c|c|c|c|c|c|c|c|}
\hline 6 & $\begin{array}{l}\text { Semangat } \\
\text { menyelesaikan } \\
\text { pekerjaan. }\end{array}$ & 32 & $43,84 \%$ & 39 & $53,42 \%$ & 1 & $1,37 \%$ & 0 & $0,00 \%$ & 0 & $0,00 \%$ & 323 \\
\hline 7 & $\begin{array}{l}\text { Berusaha } \\
\text { bekerja sesuai } \\
\text { dengan SOP } \\
\text { yang telah } \\
\text { ditetapkan } \\
\text { perusahaan. }\end{array}$ & 33 & $45,21 \%$ & 38 & $52,05 \%$ & 1 & $1,37 \%$ & 0 & $0,00 \%$ & 0 & $0,00 \%$ & 324 \\
\hline 8 & $\begin{array}{l}\text { Berkeinginan } \\
\text { mempelajari } \\
\text { hal-hal baru } \\
\text { yang berkaitan } \\
\text { dengan } \\
\text { pekerjaan yang } \\
\text { belum } \\
\text { diketahui. } \\
\end{array}$ & 21 & $28,77 \%$ & 45 & $61,64 \%$ & 4 & $5,48 \%$ & 1 & $1,37 \%$ & 1 & $1,37 \%$ & 304 \\
\hline 9 & $\begin{array}{l}\text { Bersedia } \\
\text { mengikuti } \\
\text { training/pelatiha } \\
\text { n yang telah di } \\
\text { programkan } \\
\text { oleh HRD. }\end{array}$ & 21 & $28,77 \%$ & 43 & $58,90 \%$ & 8 & $10,96 \%$ & 0 & $0,00 \%$ & 0 & $0,00 \%$ & 305 \\
\hline 10 & $\begin{array}{l}\text { Pengawasan } \\
\text { karyawan } \\
\text { terhadap absen. }\end{array}$ & 16 & $21,92 \%$ & 46 & $63,01 \%$ & 8 & $10,96 \%$ & 1 & $1,37 \%$ & 1 & $1,37 \%$ & 295 \\
\hline 11 & $\begin{array}{l}\text { HRD memotong } \\
\text { gaji karyawan } \\
\text { yang terlambat. }\end{array}$ & 1 & $1,37 \%$ & 10 & $13,70 \%$ & 15 & $20,55 \%$ & 25 & $34,25 \%$ & 21 & $28,77 \%$ & 162 \\
\hline 12 & $\begin{array}{l}\text { HRD } \\
\text { memberikan } \\
\text { surat peringatan } \\
\text { tertulis terhadap } \\
\text { karyawan yang } \\
\text { mangkir. }\end{array}$ & 8 & $10,96 \%$ & 40 & $54,79 \%$ & 13 & $17,81 \%$ & 9 & $12,33 \%$ & 2 & $2,74 \%$ & 260 \\
\hline 13 & $\begin{array}{l}\text { Bagi karyawan } \\
\text { yang melakukan } \\
\text { pekerjaan diluar } \\
\text { instruksi kerja } \\
\text { diberikan surat } \\
\text { peringatan. }\end{array}$ & 8 & $10,96 \%$ & 32 & $43,84 \%$ & 18 & $24,66 \%$ & 14 & $19,18 \%$ & 0 & $0,00 \%$ & 254 \\
\hline 14 & $\begin{array}{l}\text { Bagi karyawan } \\
\text { yang } \\
\text { melakukan } \\
\text { pelanggaran } \\
\text { peraturan } \\
\text { perusahaan } \\
\text { diberikan surat } \\
\text { peringatan. }\end{array}$ & 13 & $17,81 \%$ & 48 & $65,75 \%$ & 7 & $9,59 \%$ & 4 & $5,48 \%$ & 0 & $0,00 \%$ & 290 \\
\hline & Jumlah & 269 & $26,69 \%$ & 520 & $51,59 \%$ & $\begin{array}{c}12 \\
2 \\
\end{array}$ & $\begin{array}{c}12,10 \\
\%\end{array}$ & 69 & $6,85 \%$ & 28 & $2,78 \%$ & \\
\hline
\end{tabular}

Sumber : Data primer yang telah diolah (2015).

\section{Variabel Iklim Organisasi $\left(\mathbf{X}_{3}\right)$}

Iklim organisasi adalah suasana yang dirasakan pegawai dilingkungan PT. Indoseiki Metalutama, sehubungan dengan organisasi yang berkaitan dengan struktur tugas, 
kemampuan untuk berkembang, sentralisasi keputusan, pemberian tanggung jawab, pemenuhan kebutuhan, dan jaminan keselamatan/keamanan dan keadilan yang tercemin dalam sikap, tinglah laku karyawan letika melaksanakan tugasnya. Adapun penilaian para responden atas disiplin kerja karyawan pada PT. Indoseiki Metalutama dapat dipaparkan sebagai berikut :

Tabel 1.11

Deskriptif Variabel Iklim Organisasi

\begin{tabular}{|c|c|c|c|c|c|c|c|c|c|c|c|c|}
\hline \multirow{2}{*}{ No } & \multirow{2}{*}{ Pernyataan } & \multicolumn{2}{|c|}{ SS } & \multicolumn{2}{|c|}{$\mathbf{S}$} & \multicolumn{2}{|r|}{$\mathbf{R}$} & \multicolumn{2}{|c|}{ TS } & \multicolumn{2}{|c|}{ STS } & \multirow{2}{*}{$\begin{array}{l}\text { Skor } \\
\text { Total }\end{array}$} \\
\hline & & $\mathbf{F}$ & $\%$ & $\mathbf{F}$ & $\%$ & $\mathbf{F}$ & $\%$ & $\mathbf{F}$ & $\%$ & $\mathbf{F}$ & $\%$ & \\
\hline 1 & $\begin{array}{l}\text { Karyawan merasa } \\
\text { senang dalam } \\
\text { melaksanakan } \\
\text { pekerjaan yang } \\
\text { dibebankan } \\
\text { kepadanya. }\end{array}$ & 7 & $9,72 \%$ & 42 & $58,33 \%$ & 15 & $20,83 \%$ & 7 & $9,72 \%$ & 1 & $1,39 \%$ & 263 \\
\hline 2 & $\begin{array}{l}\text { Karyawan merasa } \\
\text { sesuai } \\
\text { minat/keinginannya } \\
\text { dengan pekerjaan } \\
\text { yang sedang } \\
\text { dilaksanakan. }\end{array}$ & 6 & $8,33 \%$ & 54 & $75,00 \%$ & 11 & $15,28 \%$ & 1 & $1,39 \%$ & 0 & $0,00 \%$ & 281 \\
\hline 3 & $\begin{array}{l}\text { Adanya kebebasan } \\
\text { yang diberikan oleh } \\
\text { atasan bagi bawahan } \\
\text { untuk bekerja sendiri. }\end{array}$ & 7 & $9,72 \%$ & 24 & $33,33 \%$ & 15 & $20,83 \%$ & 24 & $33,33 \%$ & 2 & $2,78 \%$ & 226 \\
\hline 4 & $\begin{array}{l}\text { Pekerjaan yang } \\
\text { ditugaskan dapat } \\
\text { mencapai target. }\end{array}$ & 18 & $25,00 \%$ & 42 & $58,33 \%$ & 9 & $12,50 \%$ & 3 & $4,17 \%$ & 0 & $0,00 \%$ & 291 \\
\hline 5 & $\begin{array}{l}\text { Pekerjaan yang } \\
\text { dilaksanakan tepat } \\
\text { pada waktunya. }\end{array}$ & 22 & $30,56 \%$ & 46 & $63,89 \%$ & 3 & $4,17 \%$ & 1 & $1,39 \%$ & 0 & $0,00 \%$ & 305 \\
\hline 6 & $\begin{array}{l}\text { Hasil pekerjaan dapat } \\
\text { memuaskan } \\
\text { customer. }\end{array}$ & 47 & $65,28 \%$ & 20 & $27,78 \%$ & 4 & $5,56 \%$ & 1 & $1,39 \%$ & 0 & $0,00 \%$ & 329 \\
\hline 7 & $\begin{array}{l}\text { Kesesuaian tidaknya } \\
\text { antara tenaga yang } \\
\text { tersedia dengan } \\
\text { volume pekerjaan } \\
\text { dilingkungan kerja } \\
\text { karyawan. }\end{array}$ & 6 & $8,33 \%$ & 39 & $54,17 \%$ & 24 & $33,33 \%$ & 1 & $1,39 \%$ & 2 & $2,78 \%$ & 262 \\
\hline 8 & $\begin{array}{l}\text { Pekerjaan } \\
\text { dilaksnakan dengan } \\
\text { efisien. }\end{array}$ & 17 & $23,61 \%$ & 53 & $73,61 \%$ & 2 & $2,78 \%$ & 0 & $0,00 \%$ & 0 & $0,00 \%$ & 303 \\
\hline 9 & $\begin{array}{l}\text { Karyawan dapat } \\
\text { menyelesaikan } \\
\text { pekerjaan dengan } \\
\text { prosedur yang benar. }\end{array}$ & 30 & $41,67 \%$ & 40 & $55,56 \%$ & 1 & $1,39 \%$ & 1 & $1,39 \%$ & 0 & $0,00 \%$ & 315 \\
\hline 10 & $\begin{array}{l}\text { Pada waktu jam kerja } \\
\text { karyawan tidak } \\
\text { mengerjakan } \\
\text { pekerjaan yang diluar } \\
\text { pekerjaan. }\end{array}$ & 21 & $29,17 \%$ & 38 & $52,78 \%$ & 10 & $13,89 \%$ & 3 & $4,17 \%$ & 0 & $0,00 \%$ & 293 \\
\hline
\end{tabular}




\begin{tabular}{|c|c|c|c|c|c|c|c|c|c|c|c|c|}
11 & $\begin{array}{l}\text { Pada waktu bekerja } \\
\text { mematuhi intruksi } \\
\text { kerja. }\end{array}$ & 36 & $50,00 \%$ & 35 & $48,61 \%$ & 1 & $1,39 \%$ & 0 & $0,00 \%$ & 0 & $0,00 \%$ & $\mathbf{3 2 3}$ \\
\hline 12 & $\begin{array}{l}\text { Dilingkungan } \\
\text { pekerjaan disediakan } \\
\begin{array}{l}\text { APD (Alat Pelindung } \\
\text { Diri) oleh perusahaan }\end{array}\end{array}$ & 50 & $69,44 \%$ & 19 & $26,39 \%$ & 2 & $2,78 \%$ & 1 & $1,39 \%$ & 0 & $0,00 \%$ & $\mathbf{3 3 4}$ \\
\hline & $\mathbf{2 6 7}$ & $\mathbf{3 0 , 9 0 \%}$ & $\mathbf{4 5 2}$ & $\mathbf{5 2 , 3 1 \%}$ & $\mathbf{9 7}$ & $\mathbf{1 1 , 2 3 \%}$ & $\mathbf{4 3}$ & $\mathbf{4 , 9 8 \%}$ & $\mathbf{5}$ & $\mathbf{0 , 5 8 \%}$ & \\
\hline
\end{tabular}

Sumber : Data primer yang telah diolah (2015)

\section{KESIMPULAN}

Berdasarkan analisis dan pembahasan hasil penelitian serta mengacu pada maksud dan tujuan penelitian, seperti yang telah dipaparkan pada bab sebelumnya, maka dapat ditarik kesimpulan sebagai berikut :

1. Variabel kompetensi pemimpin $\left(\mathrm{X}_{1}\right)$ terdapat pengaruh positif dan signifikan secara parsial terhadap produktifitas $(\mathrm{Y})$. Kompetensi pemimpin $\left(\mathrm{X}_{1}\right)$ memberikan kontribusi terhadap produktifitas (Y) sebesar 31,2\%. Dengan demikian sisanya sebesar 68,8\% dipengaruhi oleh variabel lain.

2. Variabel disiplin kerja $\left(\mathrm{X}_{2}\right)$ terdapat pengaruh positif dan signifikan secara parsial terhadap produktifitas $(\mathrm{Y})$. Disiplin kerja $\left(\mathrm{X}_{2}\right)$ memberikan kontribusi terhadap produktifitas $(\mathrm{Y})$ sebesar 37,3\%. Dengan demikian sisanya sebesar $62,7 \%$ dipengaruhi oleh variabel lain.

3. Variabel iklim organisasi $\left(X_{3}\right)$ terdapat pengaruh positif dan signifik secara parsial terhadap produktifitas(Y). Iklim organisasi $\left(\mathrm{X}_{3}\right)$ memberikan kontribusi terhadap produktifitas (Y) sebesar 32,3\%. Dengan demikian sisanya sebesar 67,7\% dipengaruhi oleh variabel lain.

4. Secara simultan terbukti bahwa, kompetensi pemimpin $\left(X_{1}\right)$, disiplin kerja $\left(X_{2}\right)$ dan iklim organisasi $\left(\mathrm{X}_{3}\right)$ secara bersama-sama memberikan pengaruh kuat, positif dan signifikan terhadap produktifitas $(\mathrm{Y})$. Kompetensi pemimpin $\left(\mathrm{X}_{1}\right)$, disiplin $\operatorname{kerja}\left(\mathrm{X}_{2}\right)$ dan iklim organisasi $\left(\mathrm{X}_{3}\right)$ secara bersama-sama memberikan kontribusi terhadap produktifitas $(\mathrm{Y})$ sebesar $46,9 \%$. Dengan demikian sisanya sebesar 53,1\% dipengaruhi oleh variabel lain yang tidak diteliti pada penelitian ini.

Dengan demikian untuk lebih meningkatkan produktifitas diantaranya dapat dilakukan dengan meningkatkan kompetensi kepemimpinan, disiplin kerja dan iklim organisasi. Beberapa upaya yang dapat dilakukan antara lain:

1. Pihak Manajemen perlu meningkatkan kompetensi pemimpin dengan melakukan upayaupaya dan berbagai aktivitas yang dapat meningkatkan kompetensi pemimpin. Khususnya tentang bagaimana seorang pimpinan dapat berusaha menahan emosi ketika melihat karyawan bekerja menyimpang dari SOP, harus dilakukan upaya-upaya yang lebih kreatif agar hal tersebut dapat terlaksana dengan baik. Seperti contohnya diadakannya cara pelatihan mastering emotion dan motivation trainining, bagi para pimpinan untuk melatih cara-caramenegurdanberkomunikasi yang lebih bias diterima dan teguran itu sendiri bisa menjadi motivasi bagi karyawan. 
2. Pihak Manajemen perlu meningkatkan disiplin dengan cara mengkampanyekan budaya disiplin melalui jajaran managemen terhadap karyawan. Hal tersebut untuk menjawab pemotongan gaji karyawan akibat terlambat, sehingga kesadaran dan tanggung jawab yang diberikan pada karyawan benar-benar dipahami dan mem budaya dilingkungan perusahaan.

3. Pihak manajemen perusahaan harus dapat melakukan pembagian tanggung jawab kerja yang lebih besar pada karyawannya, cara seperti ini dapat ditempuh untuk bagian atau spesialisasi kerja tertentu dengan syarat dan ketentuan yang telah disepakati atau dibuat sebelumnya, sehingga seorang karyawan yang benar-benar sesuai kualitasnya yang akan mendapatkan kepercayaan dan tanggungjawab besar tersebut. Selain itu kondisi tersebut akan memacu para karyawan untuk meningkatkan kualitas diri masing-masing.

4. Masalah produktifitas kerja karyawan yang paling harus mendapat perhatian adalah kemampuan para karyawan dalam menjaga konsistensi pelaksanaan tugas dengan selalu berupaya menjaga mutu atas hasil pekerjaannya. Bila setiap karyawan sudah mampu melakukan setiap pekerjaan sesuai dengan standar kualitas yang ditentukan maka kebebasan bagi karyawan untuk bekerja sendiri tentunya akan memperoleh kepercayaan pimpinannya.

\section{DAFTAR PUSTAKA}

[1] Abdurrahmat Fathoni, 2006, Manajemen Sumber daya Manusia, Penerbit Rineka Cipta, Jakarta.

[2] Asmiarsih,Tety, 2006, Pengaruh Pengawasan Terhadap Disiplin Kerja Pegawai Badan Kepegawaian Daerah Kabupaten Brebes, Skripsi, Semarang, Fakultas Ilmu Sosial Universitas Negeri Semarang.

[3] Apriyanto Rudy, 2002, Pengaruh Kompetensi Pemimpin, Disiplin Kerja dan Iklim Organisassi Terhadap Produktivitas Kerja Pegawai Studi' Pada Badan Pengelolaan Dan Pengendalian Dampak Lingkungan (BAPPEDAL) Propinsi Jawa Tengah, Universitas Diponegoro.

[4] Andi Juned, dkk : Pengaruh Disiplin, Kompetensi dan Kepemimpinan Terhadap Kinerja Pegawai Dinas Tenaga Kerja Kota Samarinda, Fakultas Ekonomi Universitas 17 Agustus 1945 Samarinda.

[5] Elvira Sari, 2009, Pengaruh Kompensasi Dan Iklim Organisasi Terhadap Kepuasan Kerja, ISSN 0854-3844 Vol 16.

[6] Erlina, 2008, Metodologi Peneltian Bisnis, Untuk Akuntansi dan Manajemen, "Edisi kedua", Cetakan Pertama, Penerbit USU Press, Medan.

[7] Fikri Maulidani 2010, Pengaruh Iklim Organisasi dan Kompetensi karyawan Terhadap Kinerja karyawan pada PT KSP Nasari Bandung, Manajemen Universitas Komputer Indonesia.

[8] Hasibuan, Malayu S.P, 2006, Manajemen Dasar, Pengertian, dan Masalah, Edisi Revisi, Penerbit Bumi Aksara, Jakarta.

[9] Kreitner, Robert dan Kinicki, Angelo, 2005, Perilaku Organisasi - Buku 1, Penerbit, Salemba Empat, Jakarta.

[10] Kotter, John P., dan James L. Heskett, 2006, Budaya Korporat dan Kinerja, Terjemahan: Susi Diah Hardaniati \& Uyung Sulaksana.

[11] Kuncoro, Mudrajad, 2009, Metode Riset Untuk Bisnis dan Ekonomi, Penerbit Erlangga, Jakarta.

[12] Malhotra, Naresh K, 2009, Riset Pemasaran Pendekatan Terapan Jilid 1, PT Index, Jakarta. 
[13] Miftah Thoha, 2010, Kepemimpinan dan Manajemen, Devisi Buku Perguruan Tinggi, Penerbit PT. Raja Grafindo Persada, Kakarta

[14] Noe, R., Hollenbeck, J.R., Gerhart, B., \& Wright, P.M., 2008, Manajemen Sumber Daya Manusia. Mencapai Keunggulan Bersaing, Penerbit Salemba Empat, Jakarta.

[15] Sugiyono, 2007, "Metode Penelitian Kuantitatif Kualitatif dan R\&D", Penerbit Alfabeta, Bandung.

[16] Schuler, R.S. \& Jackson, S.E., 2006, Human Resource Management, International Perspective, Mason: Thomson South-Western.

[17] Wirawan, 2009, Evaluasi Kinerja Sumber Daya Manusia : Teori Aplikasi dan Penelitian, Penerbit Salemba Empat, Jakarta. 